\title{
BIOCHEMICAL POLYMORPHISM IN CHAR (SALVELINUS ALPINUS L.) FROM LLYNNAU PERIS, PADARN, CWELLYN AND BODLYN
}

\author{
A. R. CHILD \\ Ministry of Agriculture, Fisheries and Food, Fisheries Laboratory, \\ Pakefield Road, Lowestoft, Suffolk NR33 OHT
}

Received 18.xi.76

\begin{abstract}
SUMMARY
Blood sera from char (Salvelinus alpinus L.) inhabiting four Welsh lakes were analysed for genetic polymorphisms. The transferrin and esterase loci demonstrated genetic similarities in continuous populations and genetic differences between geographically isolated populations. Whilst the genetic information obtained for the char of Llynnau Peris and Padarn would not seem to call for measures to inhibit mixing of individuals from both lakes in the event of the destruction of Llyn Peris as a suitable char habitat, it is suggested that, in the interest of conservation of natural gene pools, the distinct populations of Llynnau Bodlyn, Cwellyn and Peris/Padarn should be maintained in isolation and not altered by stocking with char from elsewhere.
\end{abstract}

\section{INTRODUCTION}

THE Arctic char has a circumpolar distribution in the Northern Hemisphere (Wheeler, 1969). Anadromous char are no longer found south of latitude $65^{\circ} \mathrm{N}$ in Western Europe and many geographically isolated populations exist (Friend 1959). The taxonomy of this species has been the subject of considerable controversy and many "species" or "subspecies" have been named on the basis of morphological and meristic evidence taken from specimens of char in various lakes in the British Isles (Day, 1887; Regan, 1911 ; Jenkins, 1936; Friend, 1959).

Electrophoretic analysis of serum proteins by Nyman (1965, 1967) revealed polymorphic esterases in Scandinavian char and the same author (Nyman, 1972) published work clarifying our knowledge of the "Salvelinus alpinus species complex" in Scandinavia and North America. Behnke (1972) summarised the information available on the systematics of Salmonid species and recognised the potential of biochemical taxonomy to supplement the evidence relating to speciation in Salvelinus alpinus.

In the British Isles, the char is found in deep lakes and as many as 15 species (Regan, 1911) or subspecies (Jenkins, 1936) have been described. The subjects of this paper are those char inhabiting four lakes in Gwynedd, North Wales; Llynnau Peris, Padarn, Gwellyn and Bodlyn (fig. 1). These fish are known locally as "torgoch" and were given the trinomial $S$. alpinus perisii by Jenkins (1936).

Two of these four lakes, Peris and Padarn, are inter-connected by a small stream, the remaining two are isolated. The contemporary char are not anadromous and movement between unconnected lakes is not possible except by artificial restocking. There is apparently no evidence that this has been carried out and thus the lakes are considered to contain indigenous relict populations of char. 


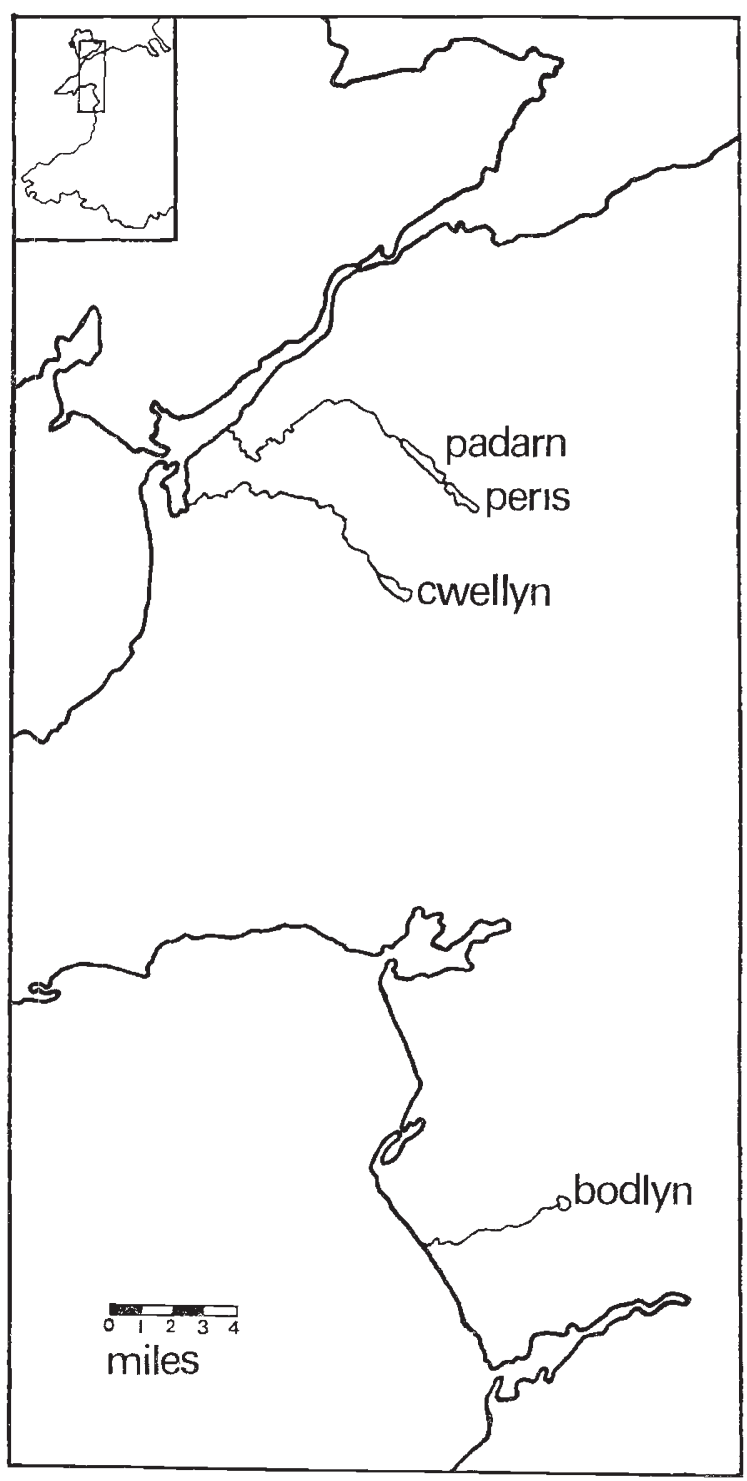

FIG. 1.-A sketch map of North Wales showing the area studies (see insert) and the position of the four lakes.

At the request of the Welsh National Water Development Authority, a survey was made to investigate the genetic relationship between these populations. Particular interest was shown in the interconnected lakes, Peris and Padarn, as it was suggested that the char inhabiting Peris were smaller than those from Padarn and that these differences might indicate "sibling speciation" analogous with that observed in some Scandinavian populations of char (Behnke, 1972; Nyman, 1972).

The upper lake, Peris, is intended as a pumped-storage reservoir in connection with the Gentral Electricity Generating Board's Dinorwic scheme 
and as a consequence will be rendered environmentally unsuitable for char due to infilling and drastic changes in the water level and temperatures. This heightened the importance of determining the genetic relationship of the char stocks if a potentially unique population was to be conserved. To a lesser extent, Llyn Ciwellyn will be subject to changes in water level following impoundment (Harvey, 1975) and the description of the genetic composition of its char population was thought to be important.

Electrophoretic analysis of the serum proteins and isozymes was carried out to investigate the genotypic relationships between the Welsh char populations.

\section{Materials AND methods}

Char were captured in gill nets in the autumn of 1974 and 1975. These nets were set in the evening and hauled in the morning and the catch was of sexually mature fish. Blood was taken from freshly killed fish either by caudal vein puncture using a $2 \mathrm{ml}$ syringe and $1 \frac{1}{2}{ }^{\prime \prime} \times 23 \mathrm{G}$ needle or by severing the body anterior to the caudal fin, in which case blood was drawn into capillary tubes. Serum was separated by centrifugation of coagulated blood and was stored at $-20^{\circ} \mathrm{C}$.

The serum proteins were separated by horizontal polyacrylamide gel electrophoresis. Two buffer systems were employed (a) modified Pouliks (Payne et al., 1972), (b) modified Pouliks (Pantelouris et al., 1970). System (a) was used with a 7 per cent gel for transferrin and esterase and system $(b)$ used with 6 per cent gel for lactate dehydrogenase and glucose-6-phosphate isomerase (Child and Solomon, in press). The number of specimens analysed from each lake were Peris-24, Padarn-24, Cwellyn-40 and Bodlyn-30.

\section{Results}

(i) Serum transferrin

Polymorphism at the transferrin (Tf) locus was reported in char by Nyman (1967) but his method was not used in population studies due to the

TABle 1

Transferrin phenotypes in Welsh lakes with the $\chi^{2}$ values obtained when comparing observed and expected phenotype numbers for Peris and Padarn populations 
diffuse nature of the separation. The method described above gave good separation (Plate I) and three patterns; a single fast band, a single slow band or both bands in combination were obtained in char sera from Llynnau Peris and Padarn. These bands were presumed to be the products of two co-dominant alleles at the transferrin locus $\mathrm{Tf} 1$ and $\mathrm{Tf} 2$, where the fast homozygote is encoded by genotype Tfl/Tfl. The observed numbers of the three transferrin phenotypes were compared to the expected numbers obtained from the Castle, Hardy, Weinburg equilibrium and no statistical differences were detected (table 1). One can assume from this that the population is in genetic equilibrium.

TABLE 2

Esterase phenotypes in Welsh lakes with the $\chi^{2}$ values obtained when comparing the observed and expected phenotype numbers for Peris and Padarn populations

\begin{tabular}{|c|c|c|c|c|c|c|c|c|}
\hline & & \multicolumn{4}{|c|}{ Phenotypes } & \multicolumn{2}{|c|}{ Gene frequency } & \multirow{2}{*}{$\begin{array}{l}95 \% \text { confidence } \\
\text { limits on } \\
\text { p.Est } 1\end{array}$} \\
\hline & & $\begin{array}{l}\text { Est } 1 / \\
\text { Est } 1\end{array}$ & $\begin{array}{l}\text { Est 1/ } \\
\text { Est } 2\end{array}$ & $\begin{array}{l}\text { Est 2/ } \\
\text { Est 2 }\end{array}$ & $\mathrm{N}_{T}$ & p.Est 1 & q.Est 2 & \\
\hline Peris & $\begin{array}{l}\text { Obs } \\
\text { Exp }\end{array}$ & $\begin{array}{l}2 \\
1 \cdot 5\end{array}$ & $\begin{array}{l}8 \\
9 \cdot 0\end{array}$ & $\begin{array}{l}14 \\
13 \cdot 5\end{array}$ & 24 & $0 \cdot 25$ & $0 \cdot 75$ & $0 \cdot 12-0 \cdot 38$ \\
\hline Padarn & $\begin{array}{l}\text { Obs } \\
\text { Exp }\end{array}$ & $\begin{array}{l}1 \\
2 \cdot 8\end{array}$ & $\begin{array}{l}14 \\
10 \cdot 4\end{array}$ & $\begin{array}{l}8 \\
9 \cdot 8\end{array}$ & 23 & $0 \cdot 35$ & 0.65 & $0 \cdot 21-0 \cdot 49$ \\
\hline Cwellyn & $\begin{array}{l}\text { Obs } \\
\text { Exp }\end{array}$ & $\begin{array}{l}40 \\
40\end{array}$ & $\begin{array}{l}0 \\
0\end{array}$ & $\begin{array}{l}0 \\
0\end{array}$ & 40 & 1.00 & $0 \cdot 00$ & - \\
\hline Bodlyn & $\begin{array}{l}\text { Obs } \\
\text { Exp }\end{array}$ & $\begin{array}{l}0 \\
0\end{array}$ & $\begin{array}{l}0 \\
0\end{array}$ & $\begin{array}{l}30 \\
30\end{array}$ & 30 & 0.00 & $1 \cdot 00$ & - \\
\hline
\end{tabular}

\section{(ii) Serum esterase}

Esterase polymorphism was reported by Nyman (1967) and was used to investigate the genetic composition of char populations in Scandinavia and North America (Nyman 1972). Three phenotypes were observed (Plate I), the fast homozygote Est 1/Est 1 is assumed to be conallelic with Est FF reported by Nyman (1965). As with transferrin, two co-dominant alleles Est 1 and Est 2 encode for the esterases. These allele frequencies were calculated and observed numbers compared with those expected if the populations were in genetic equilibrium. No statistically significant differences were detected (table 2).

\section{(iii) Lactate dehydrogenase}

Lactate dehydrogenase: LDH (EC.1.1.1.27) was present as two groups of five bands of activity corresponding to two loci for muscle LDH and two loci for heart LDH with their hybrid bands. An analogous pattern was reported in brown trout (Salmo trutta L) and rainbow trout (S. gairdnerii Richardson) by Hitzeroth et al. (1968). The anodal group $\mathrm{B}^{1} / \mathrm{B}^{2}$ was found to be less diffuse than the slower $\mathrm{A}^{1} / \mathrm{A}^{2}$ group (Plate I). All char sera examined had this pattern of $\mathrm{LDH}$ activity. 
$\overline{0}$

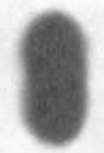

$\varangle$

खण

œu్

I

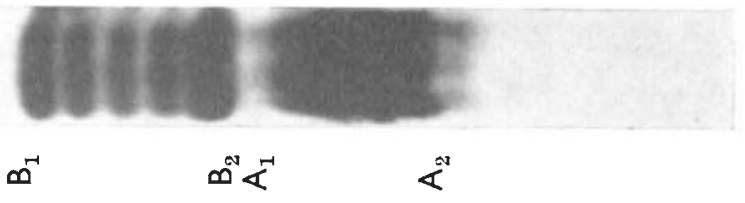

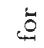

苑

$\bar{g}$

n

مั

巳

ㄹ.

罂

证

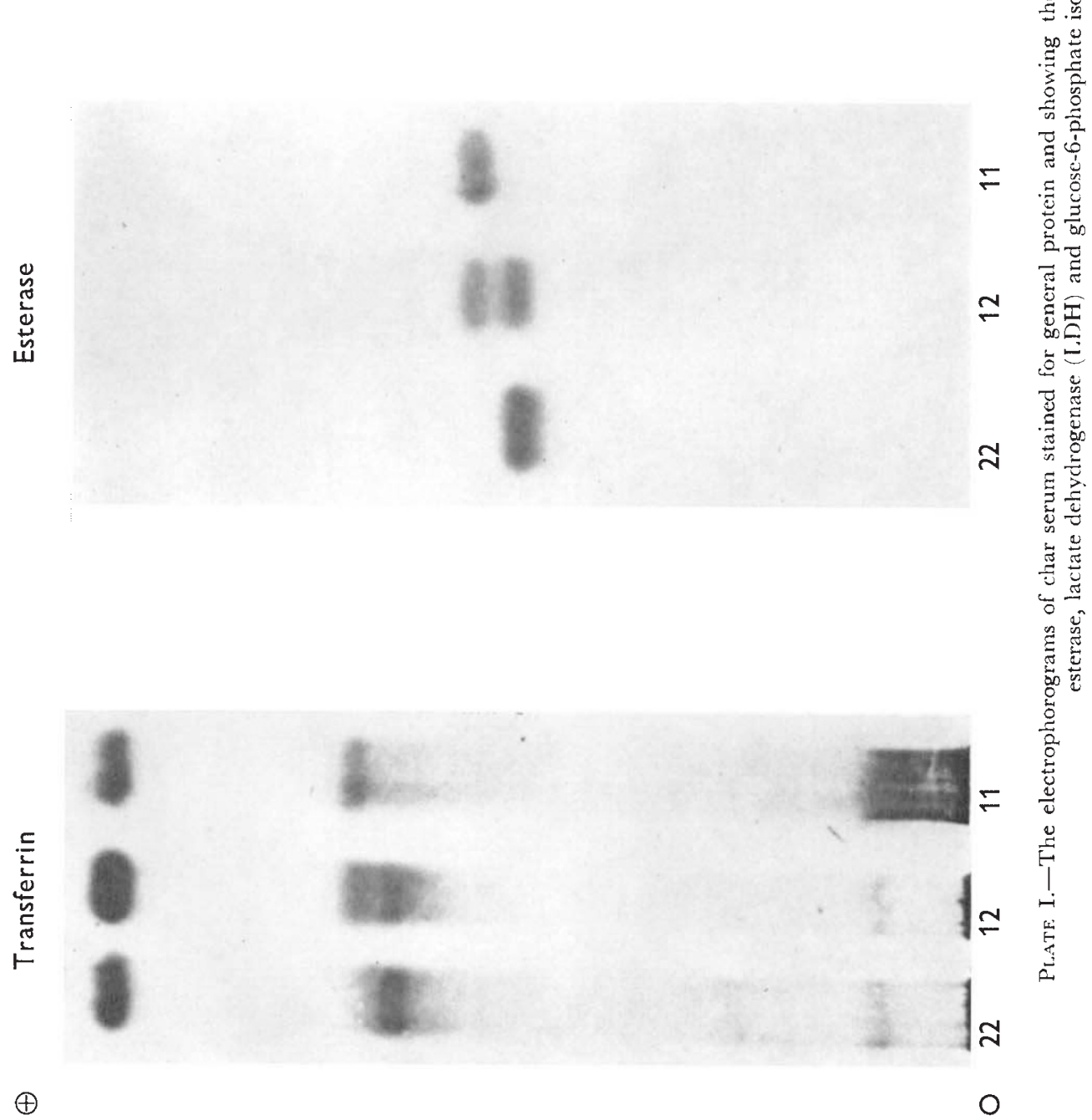




\section{(iv) Glucose-6-phosphate isomerase}

D-glucose-6-phosphate ketol isomerase: GPI (EC.5.3.1.9) has been described in many teleost species and has been shown to be a dimeric enzyme controlled by two independent autosomal loci $G p i-A$ and $G p i-B$ in certain of these species (Avise and Kitto, 1973; Dando, 1974). In all the char sera examined a six-banded pattern was recorded (Plate I). This indicates a third locus $G p i-C$ analogous to the findings reported in brook trout (Salvelinus fontinalis L) by Avise and Kitto (1973) and Schmidtke et al. (1975).

\section{Discussion}

Since no variation in the LDH or GPI isozymes was seen in all the char sera analysed, these systems would suggest a possible common origin of the Welsh stocks.

In contrast, the transferrin and esterase frequencies showed genetic differences between char from Llynnau Bodlyn, Cwellyn and Peris/Padarn.

\section{(i) Peris and Padarn}

There is no evidence to suggest genetic dissimilarity between the char caught in Llyn Peris and those caught in Llyn Padarn. Although the frequencies of both transferrin and esterase alleles differ slightly between samples, these differences are not statistically significant, there being considerable overlapping in the 95 per cent confidence limits.

A heterogeneity $\chi^{2}$ test gave values for the populations at the transferrin and esterase loci of $1.05(P=0 \cdot 5-0 \cdot 3)$ and $2 \cdot 36(P=0.2-0 \cdot 1)$ respectively.

The morphometric differences appear to be small (A. Butterworth, personal communication) and are probably due to environmental factors. There is no reason why the char of Peris and Padarn cannot be treated as one population.

\section{(ii) Bodlyn and Cwellyn}

The char samples from both Bodlyn and Cwellyn were monomorphic and hence homozygous for alleles at both the transferrin and esterase loci. The Bodlyn char were exclusively of genotype Tfl/Tfl; Est 2/Est 2. In contrast, the Cwellyn char were exclusively of genotype Tf2/Tf2; Est 1/Est 1 .

Isolation of the Welsh char populations presumably occurred at the time of the last glaciation and considerable changes in gene frequency must have taken place if all the char derived from a single ancestral stock. This variation found in the present relict population may have resulted from selection or perhaps genetic drift.

Nyman and Shaw (1971) demonstrated that the slow esterase allele (Est 2) was kinetically better adapted to low temperatures and that the frequency of the allele was correlated with latitude. If this selection mechanism acted on the Welsh char one assumes that there is variation in the temperature of the lakes studied. This is unlikely since all four lakes are at a similar latitude, between $52^{\circ} 45^{\prime} \mathrm{N}$ and $53^{\circ} 06^{\prime} \mathrm{N}$, and share similar climatic conditions. However, in the absence of temperature data from the 
lakes or controlled temperature experiments this suggestion cannot be ruled out. The selection mechanism acting upon the transferrin allele is not known.

The apparent fixation of alleles in the Bodlyn and Cwellyn populations may be explained by genetic drift. This is the random change in gene frequency occurring over generations. The effect of these changes are particularly marked in populations with a small effective size. Such random variations in gene frequency, if they result in successive reductions in the frequency of a certain allele, could lead to its extinction. As a result, small isolated populations which initially had identical gene frequencies may diverge over several generations until their genetic complements are completely different. Genetic drift occurs in random mating populations independent of and sometimes contrary to selection pressures and could explain the differences noted in the Welsh char populations where the Tfl and Est 2 alleles appear fixed in Llyn Bodlyn char and the Tf2 and Est 1 alleles are fixed in the Llyn Gwellyn char. The population sizes in these lakes is not known but the effective size, i.e., the population numbers which produce the succeeding generation, may be considerably smaller than the apparent population and genetic drift may have occurred.

Svärdson (1958, 1961) explained variation in Coregonid stocks as the result of multiple ancestral forms. The distinctive difference between Gwellyn char and those from Bodlyn and Peris/Padarn may be the result of colonisation by a second stock. Preliminary results suggest that Gwellyn char have a closer affinity to Windermere char than to those inhabiting the Welsh lakes. Expansion of this work to the other populations in Scotland and Ireland may shed more light on the problems.

It should be pointed out that due to the small sample sizes, only large deviations from equilibrium and large differences between populations will be detected. However, despite these limitations and the lack of a conclusive explanation of the mechanism leading to the genetic dissimilarities of Welsh char, the populations of Peris/Padarn, Bodlyn and Gwellyn are considered to contain genetically distinct stocks and artificial inter-mixing of these populations should be strongly discouraged in the interest of conserving the natural gene pools.

Acknowledgments. - The author thanks the Welsh National Water Development Authority - Gwynedd River Division, the Central Electricity Generating Board and the Fisheries Unit, University of Liverpool, for their help in the collection of specimens of char. I am grateful to Alan Butterworth of the Fisheries Unit for allowing me access to his unpublished results. Thanks also go to Mrs A. Forrest for her technical assistance.

\section{ReFerences}

Avise, J. C., AND KitTo, G. в. 1973. Phosphoglucose isomerase gene duplication in the bony fishes: an evolutionary history. Biochem. Genetics, $8(2), 113-132$.

BEHNKE, R. J. 1972. The systematics of salmonid fishes in recently glaciated lakes. 7 . Fish. Res. Bd. Canada, 29, 639-671.

GHILD, A. R., AND SOLOMON, D. J. 1977. Observations on morphological and biochemical features of some cyprinid hybrids. J. Fish. Biol. (in press).

DANDO, P. R. 1974. Distribution of multiple glucose phosphate isomerases in teleostean fishes. Comp. Biochem. Physiol., 47B, 663-679.

DAY, F. 1887. British and Irish Salmonidae. Williams and Norgate. London.

FRIEND, G. F. 1959. Subspeciation in British Charrs. Syst. Ass. Publ., 3, 121-129.

HARVEY, A. 1975. A discussion of the possible effects of impoundment on the char (Salvelinus alpinus L.) in Llyn Cwellyn. Welsh National Water Development Authority, Gwynedd River Division Fisheries Investigation No 5 (mimeo), p. 7. 
HITZEROTH, H., KLOSE, J., OHNO, s., AND WOLF, U. 1968. Asynchronous activation of parental alleles at the tissue-specific gene loci observed on hybrid trout during early development. Biochem. Genetics, 1, 287-300.

JENKIns, J. T. 1936. The Fishes of the British Isles both Freshwater and Salt. Warne, London. NYMAN, O. L. 1965. Variation of proteins in hybrids and parental species of fish. Rep. Swed. Salm. Res. Inst. LFI Medd., 13, 1-6.

NYman, o. L. 1967. Protein variations in Salmonidae. Rep. Inst. Freshw. Res. Drott., 47, 5-38.

NYMAN, O. L. 1972. A new approach to the taxonomy of the "Salvelinus alpinus species complex". Rep. Inst. Freshw. Res. Drott., 52, 103-131.

NYMAN, O. L., AND SHAW, D. H. 1971. Molecular weight heterogeneity of serum esterase in four species of salmonid fish. Comp. Biochem. Physiol., 40B, 563-566.

PANTElouris, E. M., ARNASON, A., AND TESCH, F-W. 1970. Genetic variation in the eel. II. Transferrins, haemoglobins and esterases in the eastern North Atlantic. Possible interpretations of phenotypic frequency differences. Genet. Res., 16, 277-284.

PAYNE, R. H., CHILD, A. R., AND FORREST, A. 1972. The existence of natural hybrids between the European trout and the Atlantic salmon. 7. Fish Biol., 4, 233-236.

REGAN, C. T. 1911. The Freshwater Fishes of the British Isles. Methuen, London.

SCHMIDTKE, J., DUNKASE, G., AND ENGEL, w. 1975. Genetic variation of phosphoglucose isomerase isoenzymes in fish of the orders, Ostariophysi and Isospondyli. Comp. Biochem. Physiol., 50B, 395-398.

svärdson, G. 1958. Specification in freshwater fish as illustrated by Coregonus. Proc. $X V$ th Inter. Conf. Zool. Sect. II (I), 137-141.

SVÄrDson, G. 1961. Young sibling fish in northwestern Europe. In Vertebrate Specification, pp. 498-513. Univ. Texas Symp.

WHEELER, A. 1969. The Fishes of the British Isles and North West Europe. MacMillan, London. 